\title{
INFLUENCE OF DIFFERENT METHODS OF CERVICAL FLARING ON ESTABLISHMENT OF WORKING LENGTH
}

\author{
INFLUÊNCIA DE DIFERENTES MÉTODOS DE AMPLIAÇÃO CERVICAL NA \\ DETERMINAÇÃO DO COMPRIMENTO DE TRABALHO
}

Dieison Nardi LAZZARETTI ${ }^{1}$, Bernardo Alievi CAMARGO ${ }^{1}$, Alvaro DELLA BONA², Volmir João FORNARI ${ }^{3}$, José Roberto VANNI ${ }^{4}$, Flares BARATTO FILHO ${ }^{5}$

\author{
1- Undergraduate dental student at University of Passo Fundo - FO-UPF. \\ 2- DDS, MMedSci, PhD in Dental Biomaterials by the University of Florida, USA, Senior Professor of Prosthodontics and Occlusion - FO-UPF. \\ 3- DDS, MSc student in Endodontics at Unaerp; Professor of Endodontics at CIE - Passo Fundo, RS, Brazil. \\ 4- DDS, MSc, PhD in Endodontics by Pernambuco Dental School (FOP/UPE); Senior Professor of Endodontics at FO-UPF. \\ 5- DDS, MSc, PhD in Endodontics by Pernambuco Dental School (FOP/UPE); Professor of Endodontics at Univille. \\ Corresponding address: José Roberto Vanni - Rua Senador Pinheiro, 224 - Cep.: 99070-220 - Passo Fundo - RS \\ Tel: +55 (54) 313-6155 - e-mail: cie@annex.com.br
}

Received: December 6, 2005 - Modification: April 18, 2006 - Accepted: August 4, 2006

\begin{abstract}
O

bjective: to investigate the influence of three different rotary systems for cervical flaring on establishment of the real working length. Material and methods: Thirty mandibular first molars were submitted to conventional endodontic access and initial working length measurement, followed by irrigation/suction of the pulp chamber with 5\% sodium hypochlorite. Teeth were randomly divided into 3 groups $(n=10)$ and cervical flaring of the mesiobuccal canals were performed using one of the following instrument systems: Group 1 - Gates-Glidden burs; Group 2 - Orifice Openers; Group 3 - La Axxess system. Two subsequent numbers of instruments of each rotary system were used and the final working length was recorded. A digital calyper was used to record the working length, in millimeters, to investigate a possible discrepancy between initial and final measurements. Results: Analysis of variance (Anova) na Tukey test revealed statistical difference between Group 1 and Groups 2 and 3 ( $\mathrm{p} £$ 0.05). Conclusions: all groups presented shorter working length after cervical flaring; groups prepared with instruments La Axxes and Orifice Opener presented the best results among the systems studied.

Uniterms: Cervical flaring; Rotary systems; Gates-Glidden burs; Cervical flaring instruments.
\end{abstract}

\begin{abstract}
RESUMO
$O$

bjetivo: determinar a influência de três sistemas distintos de instrumentos rotatórios para alargamento cervical na determinação do comprimento real de trabalho. Material e métodos: Trinta primeiros molares inferiores foram submetidos ao acesso endodôntico convencional e odontometria inicial pelo método visual, utilizando-se para irrigação/aspiração da câmara pulpar o hipoclorito de sódio a 5\%. Procedeu-se a ampliação cervical dos canais mésio-vestibulares empregando-se diferentes alargadores cervicais. De acordo com o sistema de ampliação cervical empregado, as 30 amostras foram divididas aleatoriamente em 3 grupos de 10 dentes cada. No Grupo 1 as brocas de Gates-Glidden foram utilizadas para a ampliação cervical; no Grupo 2, Orifice Openers foram empregados; e, no Grupo 3, foi usado o sistema La Axxess. Foram utilizadas em ordem crescente, duas numerações do sistema rotatório correspondente a cada grupo e, após, realizou-se a odontometria final. A leitura das duas tomadas odontométricas foi realizada com paquímetro digital, em milímetros, considerando-se duas casas decimais para averiguar a provável discrepância entre ambas as tomadas. Resultados: a análise de variância (ANOVA) e o teste de Tukey (p£ 0,05) demonstraram diferença estatística entre o Grupo 1 e os Grupos 2 e 3. Conclusões: todos os grupos apresentaram encurtamento do comprimento de trabalho após alargamento cervical; os grupos preparados com instrumentos La Axxes e Orifice Opener apresentaram os melhores resultados.

Unitermos: Ampliação cervical; Sistemas rotatórios; Brocas de Gates-Glidden; Alargadores cervicais.
\end{abstract}




\section{INTRODUCTION}

During the last years, Endodontics has been searching for new instruments, instrumentation techniques, irrigants and drugs to achieve the best cleaning and disinfection of root canals ${ }^{12}$. Within this context, cervical flaring has been one of the current concerns of investigators ${ }^{15}$.

Philippas ${ }^{16}$ mentioned that physiological or pathological continuous and progressive dentin formation in the pulp chamber floor created interferences that reduced the root canal diameter, especially at the cervical third, and thus it should be removed during endodontic treatment.

Leeb $^{7}$ investigated the effect of cervical flaring on the establishment of apical diameter of different groups of teeth and observed that the use of a single Gates-Glidden bur removed the cervical constriction allowing larger files to reach the apical portion.

Lopes and Costa Filho ${ }^{10}$ described that, in addition to the advantages of using specific instruments to prepare the root canal openings, this clinical step also provides better action of irrigation and suction, since auxiliary chemical substances may be placed close to the apical third, thereby allowing elimination of a larger amount of smear layer.

Estrela, et al. ${ }^{5}$ mentioned the main advantages of cervical flaring in Endodontics: reducing pressure during irrigation due to the possibility of overflow; deeper penetration of irrigant; effective removal of cervical contamination; reduced possibility of ledges, apical deviation or instrument fracture; better control of the active tip of the instrument, thus overcoming the influence from apical curvature by a straighter access; and an improvement of the obturation steps, especially lateral condensation. The anatomical complexity of molars, especially the mandibular molar and its mesial root, increases the difficulty of routine endodontic procedures, due to the number of root canals, curvatures or even the apical anatomical configuration with several isthmi. ${ }^{21}$

Travassos, et al. ${ }^{19}$ concluded that preparation of the cervical third of curved root canals before the use of endodontic instruments allowed straighter access to the apical region, reducing the possibility of interferences or apical deviation.

Tan and Messer ${ }^{18}$ reported that continuous dentin formation reduces the volume of the pulp chamber in different types of teeth due to the progressive narrowing of root canals, besides the appearance of cervical constrictions. These constrictions should be removed by accomplishment of cervical preparation, thus allowing more accurate working length determination and more precise establishment of the initial apical instrument diameter (IAI).

Lopes and Siqueira $\mathrm{Jr}^{11}$ stated that cervical flaring allowed the introduction of endodontic files without locking into the root canal on the pulp chamber, until the first root canal curvature is reached, thus eliminating cervical interferences to allow better establishment of the initial apical instrument (IAI).

Tan and Messer ${ }^{18}$, investigated the effect of instrument type and the influence of cervical flaring on the establishment of the IAI of molars and premolars, which pose the greatest challenge in endodontic treatment. These authors concluded that the removal of cervical dentin projections improved the insertion of larger files to the working length, thus providing criteria that should allow the achievement of a adequate biomechanical preparation.

Macedo, et al. ${ }^{13}$ evaluated the wear of the cervical third of mesiobuccal canals of maxillary molars submitted to different procedures for preparation of the root canal openings and concluded that this clinical step provides excellent configuration of the cervical root canal surface of these roots, thus allowing better uprighting of the endodontic instrument for root canal shaping.

Barroso, et al. ${ }^{3}$ investigated the influence of different methods of cervical flaring on the establishment of the IAI in maxillary premolars and concluded that larger instruments may be introduced to the real working length after cervical flaring.

Pécora, et al. ${ }^{15}$ analyzed the influence of cervical preflaring on establishment of the IAI and concluded that this step allowed the introduction of larger files to the real working length (RWL).

Therefore, the objective of this study was to investigate the influence of three different rotary systems for cervical flaring on establishment of the RWL, testing the hypothesis that there is no difference between the systems studied.

\section{MATERIALAND METHODS}

The present study was approved by the Ethics Committee of the University of Passo Fundo (UPF). The study used 30 permanent lower first molars obtained from the Tooth Bank of the Dental School (FO-UPF). Teeth were stored in $0.1 \%$ aqueous thymol solution at $9^{\circ} \mathrm{C}$ until their utilization. All teeth included in the study presented intact and completely formed roots. Before utilization, the teeth were washed in tap water for 24 hours to remove any remnants of thymol solution.

Conventional endodontic access was performed removing and contouring the pulp chamber roof and using irrigation/suction with $5 \%$ sodium hypochlorite. The working length was measured by introducing a number 10 $\mathrm{K}$ file into the mesiobuccal root canal of each teeth until the apical foramen, followed by 1-mm stepback to establish the real working length (RWL).

Teeth were randomly divided into 3 groups $(n=10)$ and the cervical flaring of the mesiobuccal canal was performed using three different rotary instruments.

Group 1 (G1) was prepared with Gates-Glidden burs in a conventional low-speed handpiece at 5,000 rpm. Preparation was initiated with number 1 bur, which was introduced 3 times until resistance was found and then removed. Irrigation/suction was performed with 5\% sodium hypochlorite, followed by utilization of number 2 bur as used for number 1 bur. The working length was re-measured as previously described.

Group 2 (G2) was prepared using nickel-titanium cervical 
flaring instruments (Orifice Openers, SybronEndo, Glendora, USA) in a TC 3000 handpiece (Nuvag, TCM Endo, Goldach, Switzerland) set at 315 rpm, at configurations 25:08 and 25:10, in increasing order of introduction, until resistance was found. The working length measurements were performed as previously mentioned.

Cervical flaring in Group 3 (G3) was performed with nickel-titanium La Axxes instruments (SybronEndo, Glendora, USA), connected to a low-speed handpiece at $5,000 \mathrm{rpm}$. The system was also used in increasing order, at configurations 20:06 and 35:06, until resistance was found. The working length measurements were performed as previously mentioned.

A digital calyper (Mitutoyo, Tokyo, Japan) was used to measure the working length, in millimeters, investigating a possible discrepancy between initial and final measurements. The differences between both working length measurements were calculated and statistically analyzed using analysis of variance (Anova) and Tukey's multiple range tests with a significance level of $5 \%$ (á=0.05).

\section{RESULTS}

Analysis of variance (Anova) revealed statistically significant differences, which were identified by the Tukey's multiple range test ( $\mathrm{p} £ 0.05$ ) and are presented in Table 1.

All groups presented shorter working length after cervical flaring. No significant differences were found between the mean values of G2 and G3, which were different from the mean values of G1.

\section{DISCUSSION}

Apical access by cervical flaring has been increasingly addressed by investigators ${ }^{4}$. This procedure aims to remove cervical interferences from the root canal openings, which represent an obstacle to free access of endodontic instruments to the apical portions of the root canal. Stresses produced on the instrument at this area increase the angle of instrumentation. Removal of these anatomical interferences allows free access, thus enhancing root canal shaping at the apical third².

Root curvatures, especially at the apical third, represent

TABLE 1- Mean and standard deviation (SD) values of the difference between the first and second working length measurements $(\mathrm{mm})$. The statistical groupings are also shown at the mean values column. Different letters indicate statistically significant difference $(p=0.05)$

\begin{tabular}{llll} 
Groups & N & Mean & SD \\
\hline 1 & 10 & $0.15631 \mathrm{~b}$ & 0.11248 \\
2 & 10 & $0.29540 \mathrm{a}$ & 0.19472 \\
3 & 10 & $0.36550 \mathrm{a}$ & 0.25121 \\
\hline
\end{tabular}

an additional difficulty to the professional, since they may be difficult to observe. The curvatures in thin, flattened root canals, as the mesial roots of molars, which represent a remarkable difficulty for preparation and several different techniques have been advocating in an attempt to solve this problem. Therefore, this study was conducted on the mesiobuccal root of the mandibular first molar because it presents difficult access in the oral cavity and it may have more than one canal ${ }^{20}$.

Teeth storage using $0.1 \%$ thymol at $9^{\circ} \mathrm{C}$ maintained the specimens hydrated and structurally stabilized, with no need of tissue fixation and absence of bacterial proliferation, thus simulating the clinical conditions and enhancing the intervention ${ }^{1}$.

This study investigated different systems used for cervical flaring to examine the effect of cervical interference removal on the establishment of the anatomical diameter of the root canal. Thus, rotary instruments were used for cervical flaring because they allow root canal preparation with larger instruments and reduce the risk of failures as ledges, perforations and zips ${ }^{17}$. In addition, the advantages of nickel-titanium instruments (Ni-Ti) and rotary instrumentation include more effective removal of debris due to the possibility of overflow and continuous rotation of instruments, faster preparation and reduction of root canal transportation ${ }^{6}$.

The instruments selection criteria for this study include the following: 1- Gates-Glidden (n. 1 and 2) are widely used as rotary instruments for cervical flaring 8 ; 2- Orifice Opener (SybronEndo, Glendora, USA) $(25.08,25.10)$ has recognized performance for cervical preparation of root canals ${ }^{9}$; and 3LAAxxess (20.06, 35.06), has recently been introduced into the market with almost no literature available and, therefore, should be investigated.

The rotary instruments used during cervical preparation following the aforementioned sequence steps, revealed to be an adequate, fast and safe procedure, as also observed by Aun, et $\mathrm{al}^{2}$.

Cervical flaring was performed following the "Free Tip Preparation” technique, using an instrumentation sequence from the lowest to the highest taper. Thus, the instrument tip is free and often act as a guide, significantly reducing the torsional fracture and providing more efficient action of the instrument, in agreement with Pécora, et al. ${ }^{14}$, yet in disagreement with Tan and Messer ${ }^{18}$, who performed cervical pre-flaring based on the "Crown-Down” technique, adapted from manual instrumentation.

Neither root perforation nor instrument fracture occurred in this study, which can be explain by the linear limit of instrument penetration, instrument introduction until resistance was found, observation of manufacturers' instructions, experience of the operator and standardization of the degree of curvature of each canal. These findings agree with Macedo, et al. ${ }^{13}$.

Therefore, the specimens submitted to pre-flaring with LA Axxess instruments (G3) produced the highest mean value difference between the first and second working length measurements, which was not statistical different form the 
mean value of G2 ( $>>0.05)$, in accordance with Pécora, et al. ${ }^{15}$.This finding may be due to the characteristics of LA Axxess instruments, such as the metal alloy properties, the taper (0.06), the inactive tip and the flute design of the active tip that allows the removal of cervical interferences without occurrence of deviations or perforations.

Along with other research results, this study contributes with the improvement of the endodontic therapy, considering the importance of a proper apical flaring of root canals.

\section{CONCLUSIONS}

- All groups exhibited shorter working length after cervical flaring;

- Considering the methods of cervical flaring to establish of the working length investigated in this study, the specimens prepared with instruments La Axxes (G3) and Orifice Opener (G2) presented the best results.

\section{REFERENCES}

1- Antoniazzi JH, Mjor IA, Nygaard-Ostby B. Assessment of the sealing properties of root filling materials. Odontol Tidskr. 1968;76:261-71.

2- Aun CE, Camargo SCC, Gavini G. Avaliação in vitro da influência do preparo cervical em curvaturas radiculares de raízes mesiais de molares inferiores. Rev Odontol Unicid. 1997;9:97-104.

3- Barroso JM, Guerisoli DMZ, Capelli A, Saquy PC, Pécora JD. Influence of cervical preflaring on determination of apical file size in maxillary premolars: SEM analysis. Braz Dent J. 2005;16:30-4.

4- Berger CR. Preparo do canal radicular-instrumentação manual. In: Berger CR, editor. Endodontia Clínica, São Paulo: Pancast; 2004. p.247-310.

5- Estrela C, Santos M, Bombana AC, Pesce HF. Análise da composição química de aços inoxidáveis de brocas Gates-Glidden de diferentes procedências. Rev Odont USP. 1993;7:251-5.

6- Hülsmann M, Schade M, Schäfers FA. Comparative study of root canal preparation with HERO 642 and Quantec SC rotary Ni-Ti instruments. Int Endod J. 2001;34:538-46.

7- Leeb J. Canal orifice enlargement as related to biomechanical canal preparation. J Endod. 1983;9:463-70.

8- Leonardo MR, Leal JM. Preparo biomecânico dos canais radiculares. In: Leonardo MR, Leal JM, editors. Endodontia: Tratamento de canais radiculares. $3^{\text {rd }}$ ed. São Paulo: Panamericana; 1998. p.333428.

9- Leonardo MR, Leonardo RT. Sistemas rotatórios: princípios gerais In: Leonardo MR, Leonardo RT. Sistemas rotatórios em Endodontia: instrumentos de níquel-titânio. São Paulo: Artes Médicas; 2002. p.4957.

10- Lopes HP, Costa Filho AS. Contribuição para o estudo de uma variação de técnica no preparo biomecânico dos canais radiculares, utilizando-se de brocas de Gates e de Largo. Rev Bras Odontol. 1990;47:16-22.
11- Lopes HP, Siqueira Jr JF. Preparo químico-mecânico dos canais radiculares. In: Lopes HP, Siqueira Jr JF, Elias CN. Endodontia biologia e técnica, $2^{\text {nd }}$ ed. Rio de Janeiro: Guanabara Koogan; 2004. p.419-80.

12- Lumley PJ. Cleaning efficacy of two apical preparation regimes following shaping with hand files of greater taper. Int Endod J. 2000;33:262-72

13- Macedo MCS, Cardoso RJA, Bombana AC. Avaliação do desgaste do terço cervical dos canais mésio-vestibulares de molares superiores submetidos a diferentes procedimentos de preparo de suas entradas. J Bras End. 2003;4:317-23.

14- Pecora JD, Capelli A, Seixas FH, Guerisoli DMZ, Marchesan MA. Preparo da Ponta Livre (Free Tip Preparation). Available at: URL: http://www.forp.usp.br/restauradora/depart.htm. Accessed on June $2^{\text {nd }}$ 2004.

15- Pécora JD, Estrela C, Spanó JCE, Guerisoli DMZ. Influence of cervical preflaring on apical file determination. Int Endod J. 2005;38:425-98.

16- Philippas GG. Influence of occlusal wear and age on formation of dentin and size of pulp chamber. J Dent Res. 1961;40:1186-98.

17- Sonntag D, Guntermann A, Kim SK, Stachniss V. Root canal shaping with manual stainless steel files and rotary Ni-Ti files performed by students. Int Endod J. 2003;36:246-55.

18- Tan BT, Messer H. The effect of instrument type and preflaring on apical file size determination. Int Endod J. 2002;35:752-8.

19- Travassos RMC, Rodrigues VMS, Pontes MMA, Alves DF. Estudo de duas técnicas de preparo cervical associadas ao sistema rotatório Pow-R. Rev Cons Reg Odontol Pernambuco. 2001;4:43-8.

20 - Vier FV, Tochetto FF, Orlandin LI, Xavier LL, Michelon S, Barletta FB. Avaliação in vitro do diâmetro anatômico de canais radiculares de molares humanos, segundo a influência da idade. J Bras Endod. 2004;5:52-60.

21- Walton RE, Torabinejad M. Cirurgia de acesso e determinação do comprimento. In: Walton RE, editor. Princípios e prática em Endodontia. $2^{\text {nd }}$ ed. São Paulo: Santos; 1997. p.180-200. 